\section{Kilka uwag na temat twórczości}

\section{Krzysztofa Boguszewskiego}

ALEKSANDER STANKIEWICZ

INSTYTUT HISTORI SZTUKIUKSW

Krzysztof Aleksander Boguszewski należy do nielicznych polskich malarzy nowożytnych, którym poświęcono dość dużo uwag w literaturze naukowej. Jednak od czasu publikacji międzywojennych nie próbowano krytycznie przeanalizować jego artystycznego dorobku i wskazać w związku z tym nowych postulatów badawczych.

Artysta był wzmiankowany juz w opracowaniach XIX-wiecznych starożytników i w literaturze krajoznawczej', ale pierwszą i jak dotąd najobszerniejszą analizę obrazow Boguszewskiego zawdzięczamy Irenie Głębockiej-Piotrowskiej. Według niej malarz korzystał $\mathrm{z}$ doświadczeń Hermana Hana, a jego styl, charakteryzujący się dekoracyjnością i jednocześnie złożonością kompozycii, badaczka określała jako tradycyinyizaliży od prac twórćw nidercyjny izalezny od srac twórcow niderAutorem programu ideowego jego obrazów mieliby być zleceniodawcy².

N. Pajzderski, Poznań, Lwów-Warszawa 1922, s. 89. 2. Głębocka-Piotrowska, Krzysztof Boguszewski i poznańska szkoła malarska na początku XVII wieku, „Kronika Miasta Poznania” 1928, nr 2-3, r. 6, s. 115-159,
W tym samym czasie Marian Mika, odkrywca nieanalizowanych jak dotąd źródeł archiwalnych dotyczących artysty, określił jego styl malarski jako typowo polski³. Bardzo krytycznie na temat badań Ireny Głębockiej-Piotrowskiej wypowiedział się Alfred Brosig, dowodząc, że na podstawie kilku prac tego malarza trudno próbować wysnú jakieś wnioski 4 . Genezy

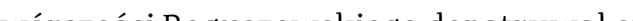
w twórczoscizakonj, prytoczy tez w twórczosci zakonnej, przytoczył też fragmenty jego testamentus. Wnioski tych badaczy znalazły się w biogramie artysty autorstwa Krystyny Sinko ${ }^{6}$.

Propozycje dotyczące odczytania ikonografii dzieł Krzysztofa Boguszewskiego przyjął i rozwinął Władysław Tomkiewicz, który analizował je w kontekście aktualizacjip. Autorytet badacza sprawiłł że więsszość

\section{M. Mika, K.A. Boguszewski, królewski serwitor-}

, naniu,,,Kronika Miasta Poznania"

1934 , nr 4, r. 12, s. 386-390.

4A. Brosig, Materiaty do historii sztuki wielkopolskiej, Taznan 1934, szp. XII-XXII.

$6 \mathrm{~K}$ Sinko Bogus 178 . K. Sinko, Boguszewski Krzyszztof Aleksander, w: Pols
stownik biograficzny, t. 2, Kraków 1936, s. 219-220.

7 W. Tomkiewicz, Aktualizm i aktualizacja w malarstwie polskim XVII wieku, ,Biuletyn Historii Sztuki”" 1951,
nr 2-3, t. 13, s. 10-16. Przedruk w: tenże, Pedzlem rozmaitym. Malarstwo w okresie Wazów w Polsce, jego interpretacji przyjęto w późniejszych opracowaniach jako fakty.

W ramach przygotowania katalogu wystawy malarstwa wielkopolskiego Aniel Sławska jako pierwsza zaliczyła do dorobku artysty obraz ukazujący św. Pawła z kościoła cysterskiego w Paradyżus. Prawie w tym samym czasie nieznane dotąd dane na temat pochodzenia malarza odnalazł ks. Janusz Nowacki', natomiast o architekturze w pracach Boguszewskiego w kontekście sztuki ok. 1600 r. pisał Tadeusz Chrzanowskiio. W późniejszych latach Aniela Sławska nieco szerzej zajeła się jeoo działalnością, cytując dotychezasow zaliczyć do dorobku malarza niektóre przedstawienia z pobernardyńskiego kościoła w Sierakowie ${ }^{12}$. Jej propozycje przyjęła część badaczy

Znaczącym sukcesem było odkrycie przez Janinę Ruszczycównę wzmianek źródłowych na temat niezachowanego obrazu Boguszewskiego Bitwa pod Grunwaldem. Autorka jako pierwsza zwróciła uwagę na dobre opanowanie przez artystę techniki malarskiej i opublikowała pomijane dotąd przez badaczy fakty dotyczące jego życia ${ }^{14}$

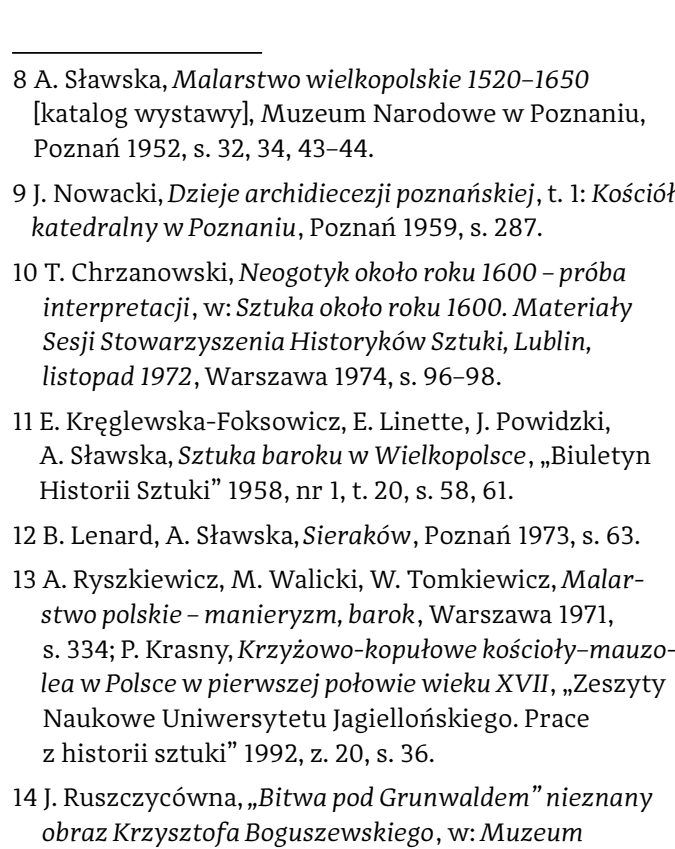

wu na późniejsze wnioski Franciszka Stolota, który w biogramie malarza zamieszczonym w Słowniku artystów polskich uznał go za twórcę odosobnionego i wybitnego, zgodził się także co do wpływu na jego twórczość Hermana Hana ${ }^{15}$. Swoje wnioski powtórzył wiele lat później, tym razem uznajac malarza za prowincjonalnegoce miniaturzystę, $z$ koleiwedhug

\section{i twórca. Studia z historii sztuki i kultury ku czci Prof.} Warszawa 1969, s. 443-457.

15 F. Stolot, Boguszewski Krzysztof Aleksander, wr: Stow nik artystów polskich i obcych w Polsce działajagcych (zmarłych przed 1966 r.). Malarze - rzeżbiarze - graficy t. 1, red. J. Maurin-Białostocka i in., Wrocław-Warszawa-Krakow-Gdansk 1971, s. 198-199. 16 S. Krzysztofowicz-Kozakowska, F. Stolot, Historia 


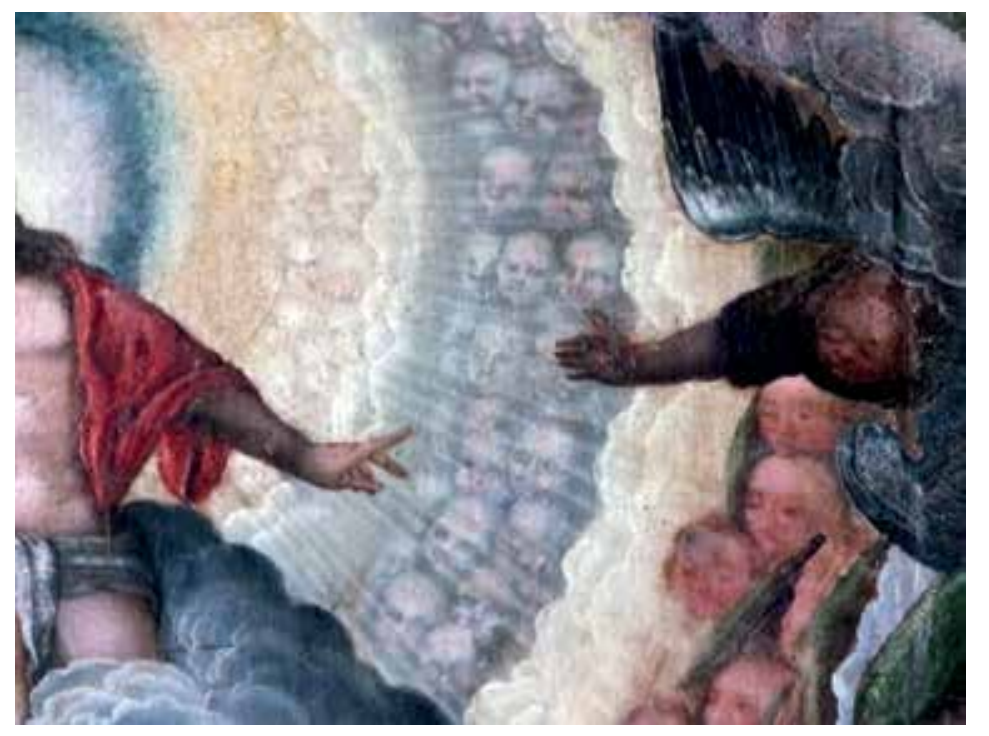

2. Krzysztof Boguszewski, fragment obrazu Wjazd św. Marcina do Amiens, 1628 r. katedra w Poznaniu. Fot. W. Hildebrandt

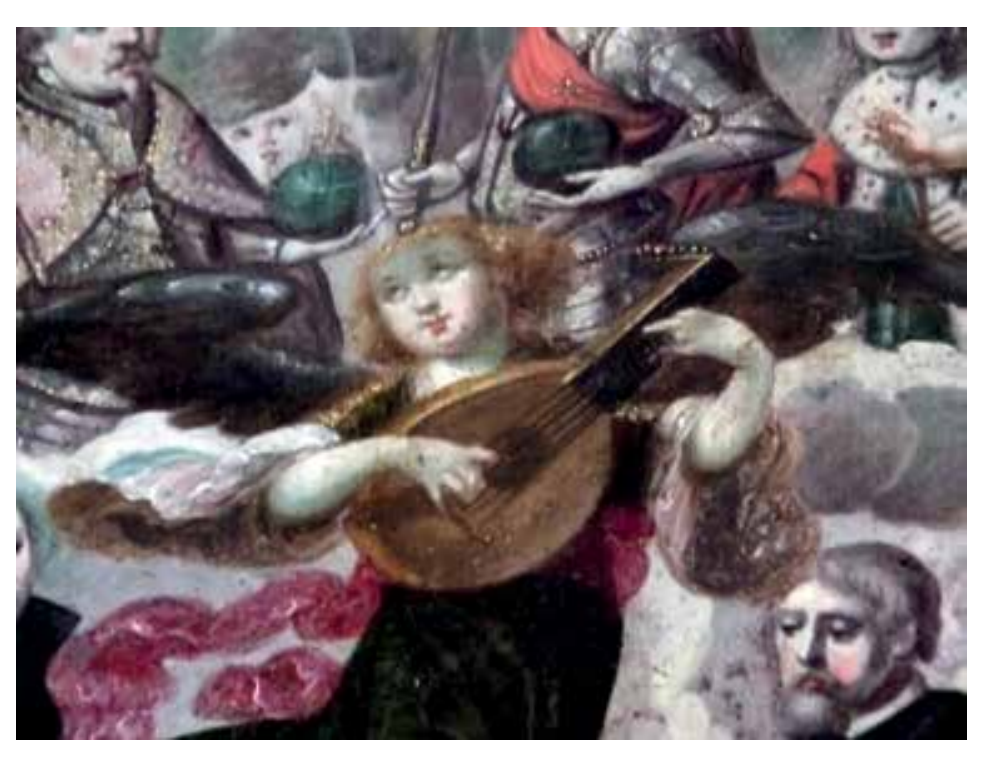

Krysztof Boguszewski (?), fragment obrazu Niebieskie Jeruzalem, ok. 1628 r., katedra w Poznaniu. Fot. W. Hildebrandt

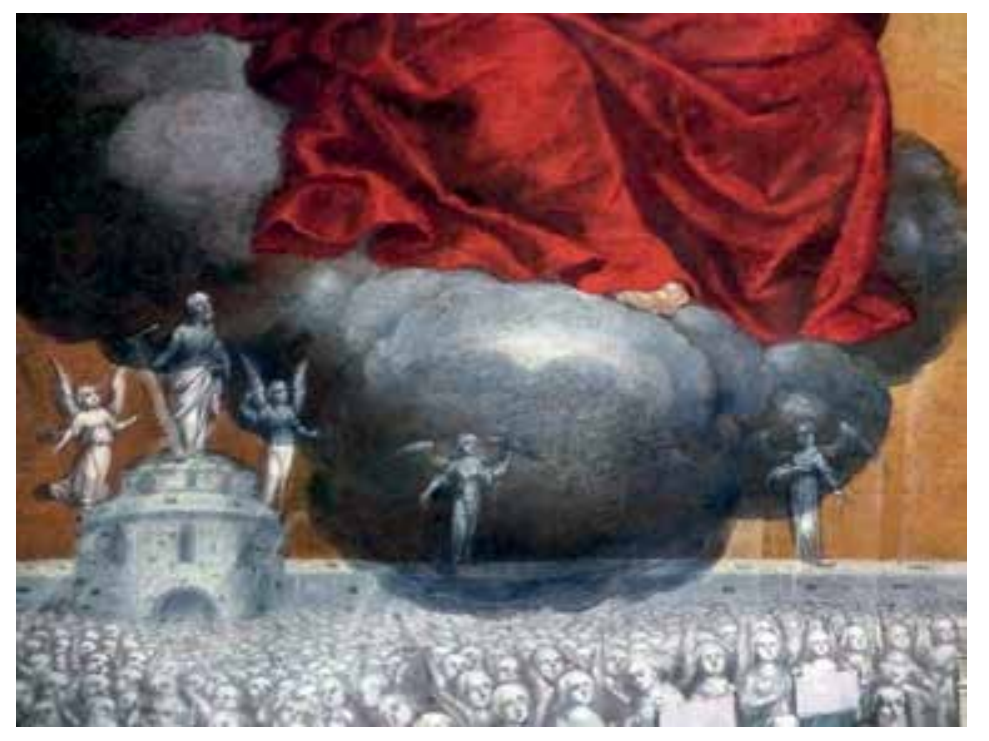

4. Krzysztof Boguszew Niebieskie Jeruzalem, ok. 1628 r., katedra w Poznaniu. Fot. W. Hildebrandt
5. Krzysztof Boguszewski (?), Obraz Święty

Paradyżu, ok. 1628 r. Fot. A. Stankiewicz

Mariusza Karpowicza Boguszewski był samoukiem, a wpływ twórczości Hana możn dostrzec u niego jedynie w zakresie kompomiałby mieć swoje korzenie w neobizantynizmie, wynikającym z reformy potrydenckiej Kościoła ${ }^{17}$. Domniemany dorobek Krzysztofa Boguszewskiego wciąż powiększano, często porównując nowe dzieła z pracami zaledwie mu atrybuowanymi ${ }^{18}$.

Nieco miejsca Boguszewskiemu poświęcił ks. prof. Janusz St. Pasierb, który poczatkowo wspominal jego prace w konpoczét kowo wspofimaryjno ch relacji do dzieł Hermana Hana i Bartłomieja Strobla ${ }^{19}$ Część wniosków powtórzył w oparciu o publikacje Ireny Głębockiej-Piotrowskiej i Władysława Tomkiewicza w monografi $\mathrm{Hana}^{20}$ oraz w opracowaniu tematu Niepokalanego Poczęcia'.

Niedawne badania naukowe dotyczace twórczości Boguszewskiego nie wniosły więcej materiału źródłowego czy też prowięcej meria zród pozycji interpretacyi prób upoza dkowania dorobku malarza. Z pewnością na uwagę zasługuje dokona ostatnio konserwacja obrazu Wjazd św. Marcina do Amiens ${ }^{22}$. Propozycje odczytan jego ikonografii autorstwa Władysława 17 M. Karpowicz, Sztuka polska XVII wieku, Warszawa
1975, s. 65, 67.

$18 \mathrm{~J}$. Wolski, Dwa wizerunki w kościele parafialnym w Biechowie, w: Ars una - prace z historii sztu red. E. Wanoylo, Pozhan 1976, s. 105-112.

19 J.St. Pasierb, Problemy ideowe i formalne pomorskich Twielkopolskich przedstawien "Koronacil Madonny " nr 1-2, s. 154, 161, 190, 209.

20 Tenże, Malarz gdański Herman Han, Warszawa 1974, s. $167,171,174,233,244,259,267,268$.

21 M. Biernacka, T. Dziubecki, T.H. Graczyk, J.St. Pasierb, Maryja Matka Chrystusa, w: Ikonografia nowożytnej. sztuki kościelnej w Polsce. Nowy Testament,
red. J.St. Pasierb, t. 1, Warszawa 1987, s. 70 . red. J.St. Pasierb, t. I, Warszawa 1987, s. 70 , 22 B. Wrońska, Wjazd św. Marcina do Amiens z poznańskiej

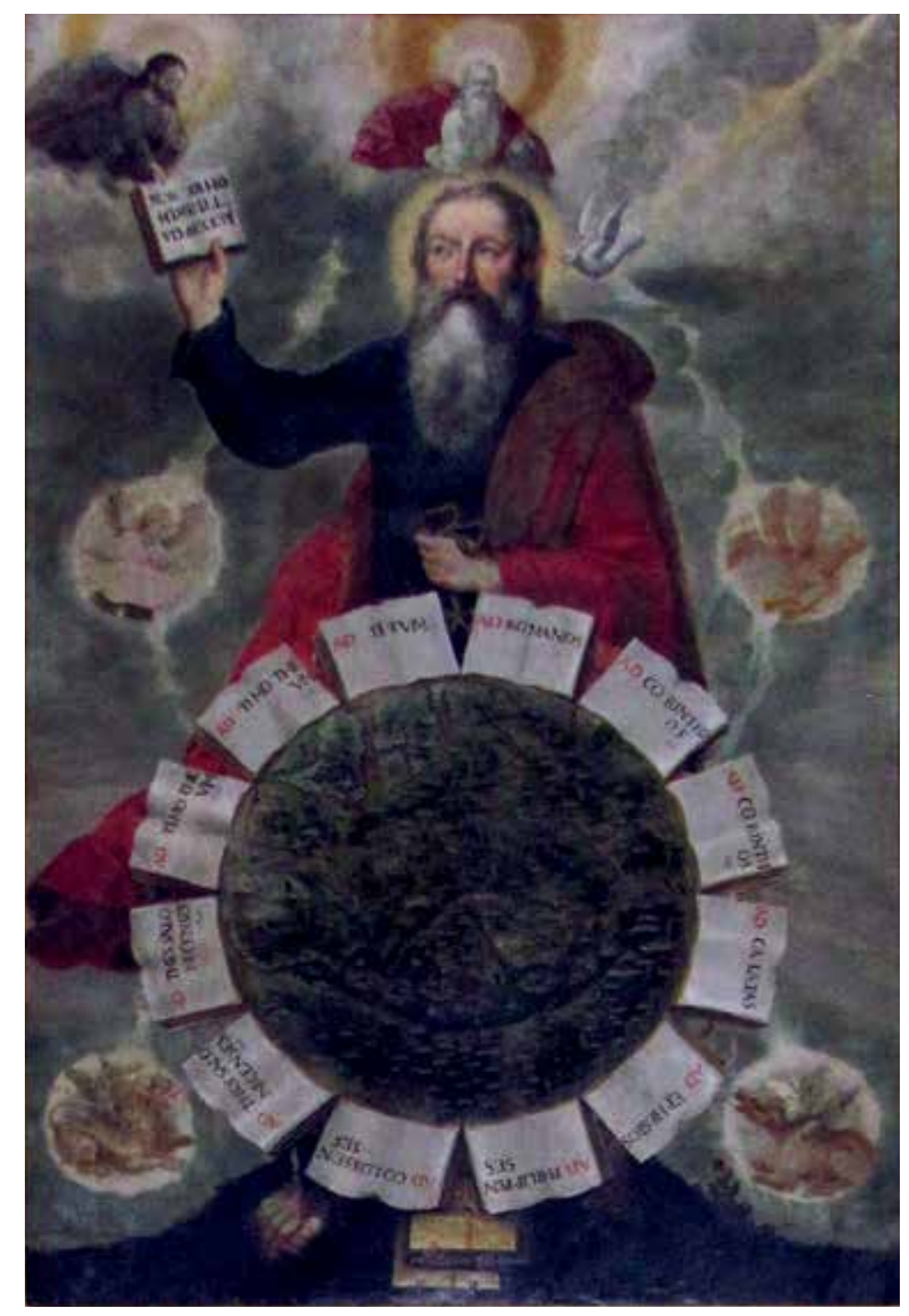

Tomkiewicza zostały powtórzone przez Jacka Żukowskiego ${ }^{23}$

Dość znaczna ilość zróżnicowanych opinii zaprezentowana przez specjalistów zachęca do rewizji dotychczasowych wniosków. Punktem wyjścia do tych rozważan powinny być przede wszystkim zr im źródło Krzysztof Aleksander Boguszewski wywodził się z drobnej szlachty z diecezji chełmskiej² ${ }^{24}$ Do stolicy Wielkopolski przybył w orszaku nowego biskupa poznańskiego,

$23 \mathrm{~J}$. Żukowski, Kryptoportrety polskich władców w malarstwie sakralnym XVII i XVIII wieku, ,Rocznit Historii Sztuki" 2012, t. 37, s. 185

24 J. Nowacki, dz. cyt., s. 287, przyp. 11; J. Ruszczycówna, 


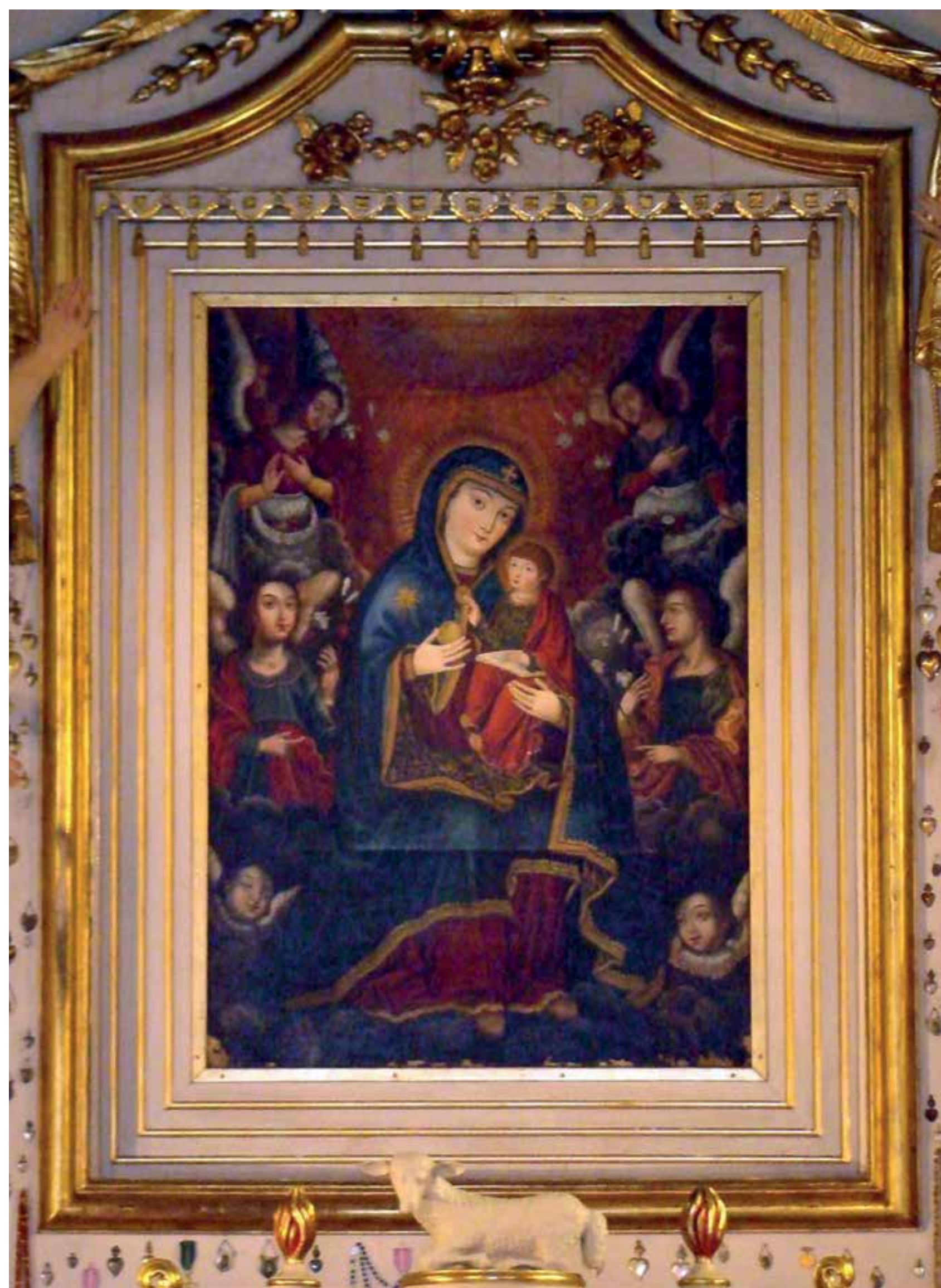

6. Krzysztof Boguszewski przemal.(?),

(a)

w Biechowie, ok. 1632 r. Fot. A. Stankiewicz

Jana Wężyka, w roku $1624^{25}$. Szlachcic, malarz który osiaggnał arte pictoria excellentiam" otrzymał tytuł serwitora królewskiego od Zygmunta III Wazy w Gołuchowie dnia 7 sierpnia 1623 r. dzięki wstawiennictwu bliżej dziś nieznanych magnató ${ }^{26}$.

Od зo października 1630 r. był proboszczem w parafii św. Wojciecha w Poznaniu, a świę cenia kapłańskie przyjął 19 kwietnia 1631 r W 1634 r., na rok przed swoim zgonem został kanonikiem przy kościele pw. św. Ma Magdaleny w Poznaniu ${ }^{28}$. Nigdy nie był sekretarzem królewskim ${ }^{29}$

Dysponujemy informacjami źródłowymi na temat dwóch omawianych jak dotąd szerzej w literaturze prac malarza - Wjazdu św. Marcina do Amiens (il. 7), namalowanego w roku 1628 na polecenie i według koncepcji opata cystersów w Paradyżu, Marka Lentowskiego (Łętowskiego) 30, oraz Bitwy pod Grunwaldem, datowanej na lata ok. 1627-1631, powstałej na zamówienie kasztelana śremskiego,

Abrahama Ciświckiego, a dedykowanej królowi Zygmuntowi III Wazie i jego synowi, Władysławowi ${ }^{31}$. W latach 1631-1635

Krzysztof Boguszewski zaangażował się

Krzysztor Boguszewskizangażował się

w fundację ołtarza bractwa Anioła Stróża

w poznańskim kościele pw. św. Wojciecha, co zresztą było podstawą dla części autorów do atrybucji malarzowi obrazu w nastawie ${ }^{32}$. Dnia 13 stycznia 1635 r. Boguszewski sporządził swój testament i jest to ostatnia

25 J Nowacki, dz. cyt., s. 287;. Ruszczycówna, dz cyt, s. 45 . 26 I. Głębocka-Piotrowska, dz. cyt., s. 181-182;

J. Ruszczycówna, dz. cyt., s. 450, 451 (tu inna paginacja
wodnośniku do źródła). Tekst dokumentu: Archiwumm wodnośniku do źródłal. Tekst dokumentu: Archi Główne Akt Dawnych w Warszawie,
Koronna, sygn. MK170, K. 387-387v.

27 M. Mika, dz. cyt., s. 387; j. Nowacki, dz. cyt., s. 287 przyp. 11; J. Ruszczycówna, dz. cyt., s. 451; F. Stolo

28 M. Mika, dz. cyt., s. 388.

29 Por. F. Stolot, dz. cyt, s. 198

30 I. Głębocka-Piotrowska, dz. cyt., s. 129

31 J. Ruszczycówna, dz. cyt., s. 451. 32 I. Głębocka-Piotrowska, dz. cyt., s. 205-206; M. Mika wzmianka źródłowa dotycząca jego działalności ${ }^{33}$

Analizując fakty z życia malarza i poszczególne zamówienia, można dojść do wniosku, że Krzysztof Boguszewski był kilkakrotnie zmuszony zmieniać swoich patronów. Zdaniem autora niniejszego artykułu inaczej, niż przedstawiano to dotychczas, rysuje się kwestia jego artystycznego wykształcenia. Jest mało prawdopodobne, by nauczył się rzemiosła malarskiego od Hermana Hana, jak chciała tego część badaczy. Skoro już w roku 1627 otrzymał od Abrahama Ciświckiego zlecenie na namalowanie wspomis jo o zlecenie na naloBoguszewski musial być wówczas znanym artystą. Nie mogło być mowy o złożeniu zamówienia u kogos o wątpliwych umiejętnościach, skoro w Poznaniu działał cech malarzy, zrzeszający twórców, których prace koneser sztuki Krzysztof Opaliński porównywał do zakupionych przez brata Łukasza obrazów niderlandzkich. Magnat pisał do niego w jednym z listów, że nakupił takich błazeństw dziecinnych, że w Poznaniu dostaby tego wszystkiego ilepij" z z pewnosciascena batalstyczna iobla na wspotioscią scena batalistyczna robiła na współczesnych wrazenie, skoro malarz Daniel Schulz wyprosił płótno w roku 1669 u króla Jana Kazimierza Wazy i ofiarował rajcom, którzy umieścili je w gdańskim ratuszu ${ }^{33}$.

Niestety, nie sa jak dotąd znane wczesne dzieła Krzysztofa Boguszewskiego. Byc może faktycznie należałoby genezy jeo prac szukać w cechowym malarstwie Lublina lub Lwowa. Wiadomo, ż w kócu wieku XVI i poczatku XVH jedynym zechen malarzy w Rzeczyospolitej w ktory kta-

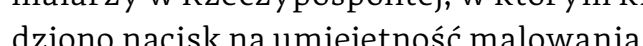
scen batalistycznce whose malowania scen batalistycznych w ramach egzaminu

33 M. Mika, dz. cyt., s. 388

34 Listy Krzysztofa Opalińskiego do brata £ukasza

1641-1653, red. R. Pollak, oprac. M. Petzy

A. 


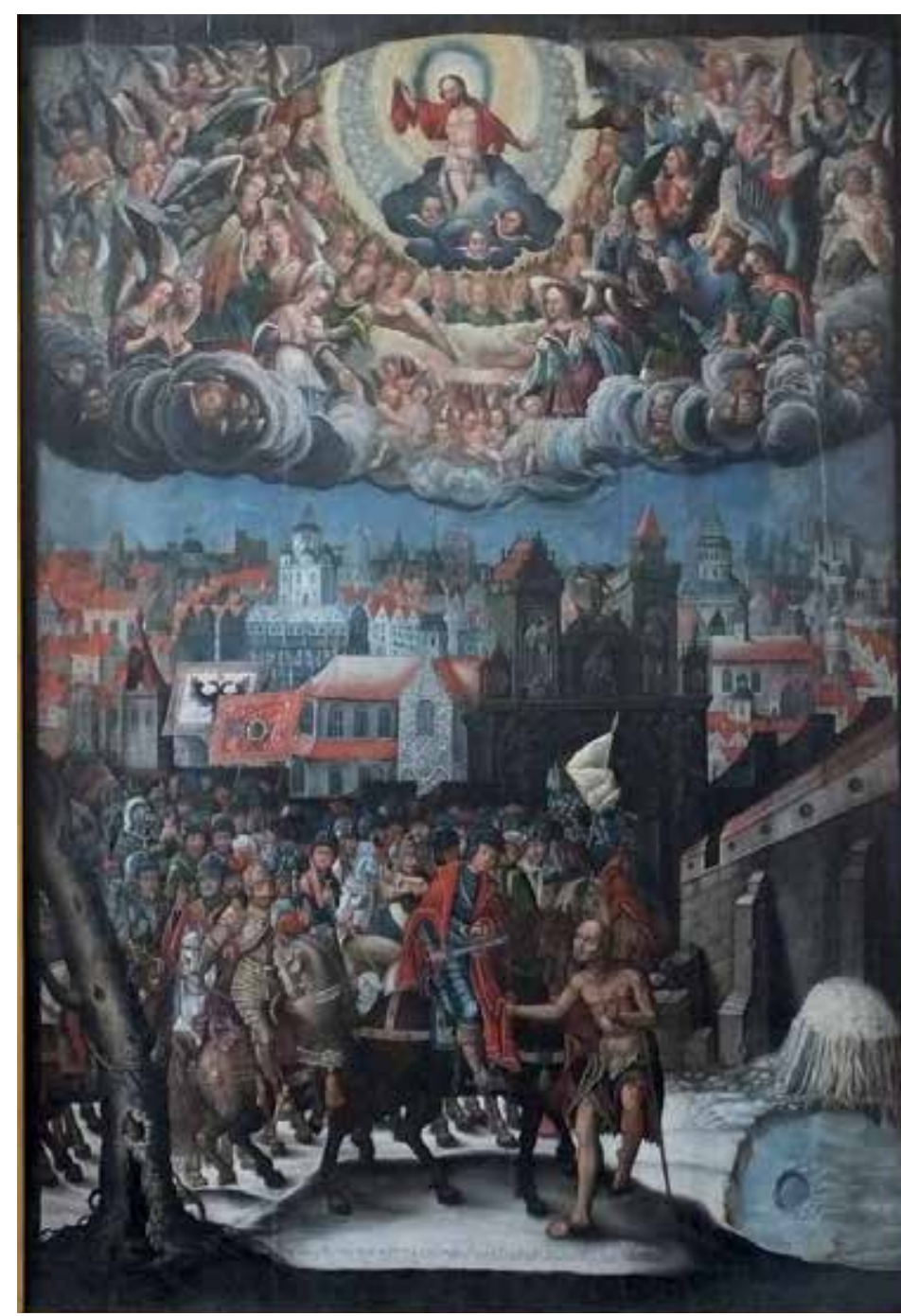

wyzwalającego na mistrza, była lwowska konfraternia ${ }^{36}$

Otrzymanie przez Krzysztof Boguszewskiego w roku 1623 tytułu królewskiego serwitora na prośbę możnych panów oznacza, że to dla nich wykonywał swoje pierwsze zamówienia. Jego przybycie w orszaku biskupa Wężyka do Poznania jest z kolei dowodem na protekcje artysty przez duchownego. $\mathrm{W}$ chownego. W 1627 r., gdy jego opiekun zost prymasem i opuścił Poznańskie, Krzyszto Boguszewski otrzymał zlecenie od Abrahama Ciświckiego, a w 1628 r. pracował

36 W konstytucii brackiej z 1596 r. ubiegający się o tytu mistrza był zobowiazzany wykonać przedstawien batalistyczna. T. Mańkowski, Lwowski cech malarzy wXVI IXVII wieku, Lwów 1936, s. 337; W. Tomkiewic 7rrzysztof Boguszewski, Wjazd św. Marcin do Amiens, 1628 r., katedra w Poznaniu. Fot. A. Stankiewicz

już dla opata Łętowskiego. Trudno więc z powodu wykonania tych kilku zamówien utrzymać o nim opinię jako o zakonnym malarzu", jak chieli tego niektórzy bym $\mathrm{cze}^{37}$. Tym bardziej, że dopiero w 1629 r. zosta $\mathrm{cze}^{37}$. Tym bardziej, że dopiero w 1629 r. został
klerykiem, a święcenia kapłańskie przyjął klerykiem, a święcenia kapłaniskie przyją dwa lata potem, juz pod koniec życia. Krzysztof Boguszewski mógł korzystać z protekcji cystersów, usamodzielniając się ostatecznie w sensie prawnym, ale też finansowym po wstąpieniu do stanu duchownego. Nowe informacje, na które dotychczas nie zwrócił uwagi żaden z badaczy zajmujących się twórczością Boguszewskiego, przynosi jego testament. W swej ostatniej woli malarz prosił o przekazanie właścicielom ukończonych przez niego już prac,

przechowywanych w jego poznańskiej pracowni. Wymienił „obraz P. Marii na półtor okna nad oknem do kaplicy różańcowej w Otorowie, obraz P. Marii na drzewie do św. Wojciecha, obraz Marii Magdaleny na półtora łokcia i św. Franciszka ma otrzymać Opaliński do Wagrowca, dwa obrazki na miedzi malowane -jeden Translatio Cruts i drugi in Sepulchro w ramach, na których są cherubinkowie srebrni do kościoła Bożego Ciała to iest do szkaplerze P. Najświętszej, obraz św. Antoniego na miedzi otrzymać ma Jegomość Pani Woj. Poznańska - do Sierakowa”. Ponadto, „obrazy drukowane, farby i przyrządy malarskie zabrać ma Hanusz, czeladnik jego" ${ }^{38}$

$$
\text { Z powyższego dokumentu wyraźnie }
$$
nię w Poznaniu któną nalezabbyu miejsowić w okolicy bądź nawet na plebanii parafi św. Wojciecha. W pracy pomagał mu nieznany bliżej czeladnik Hanusz, który odziedziczył po nim farby, zbiór rycin oraz przyrządy malarskie - malarczyk nie był więc tylko

\section{A. Brosig, dz. cyt., s. $176,177,178$.}

38 Archiwum Archidiecezji Poznańskiej, Acta Causarum 1633-1635, sygn. AC 144, k. 337v-344; M. Mika, jego pomocnikiem, ale też uczniem. Bardzo interesujące są informacje na temat prac, które Krzysztof Boguszewski zdążył ukończyć tuż przed sn czyc tuz przed smiercia. Niestety, nie zachowały się wsponnnine obrazy przeznaczon do Sierakowa, malowane dla Zofii z Kostków Opalińskiej, czy Opalińskiego (moż Krzysztofa), ani też te do kaplicy Szkaplerza przy kościele pw. Bożego Ciała w Poznaniu. Kroniki oraz wizytacje kościelne milczą na ten temat. Udało się natomiast znaleźc dzieło, które odpowiadałoby notatce o namalowaniu wizerunku Matki Bożej do XVI-wiecznego kościoła parafialnego w Otorowie przy ktorymo w Otorowie, przy ktorym od 1640 r. działało . uznawany za łaskami słynący obraz w pie rzymskiego wizerunku Matki Bożej Śnieżnej (Salus Populi Romani) w otorowskie świątyni faktycznie datowany jest na pierwszą ćwierć XVII w..40 (il. 1). Twarz Maryi wydaje się podobna do innych kobiecych typów fizjonomicznych, które wyszły spod pędzla malarza, co w kontekście treści Krzysztofa Boguszewskiego. Ograniczona ilość potwierdzonych jak dotąd źródłowo prac nie zniechęciła badaczy do związania z nim znacznej liczby dzieł. Sytuację tę można traktować jako typowy w polskiej literaturze historyczno-artystycznej przypadek, gdy do każdego wybijającego się ponad przeciętność dzieła należy przypisać jakieś znane nazwisko. Wstępny przegląd realizacji wiąz Wstępny przeglad realizacji wązanych z Krzysztofen Boguszewskim pozwala na okreslenie ich zakresu po rzucenie części z nich, jako powstałyc w innych, anonimowych warsztatach.
Punktem wyjścia do scharakteryzoPunktem wyjścia do scharakteryzo-
a stylu Boguszewskiego może być

39 Katalog zabytków sztuki w Polsce, t. 5: Województwo poznańskie, z. 23: Powiat szamotulski, oprac. 40 Tamże, s. 17.
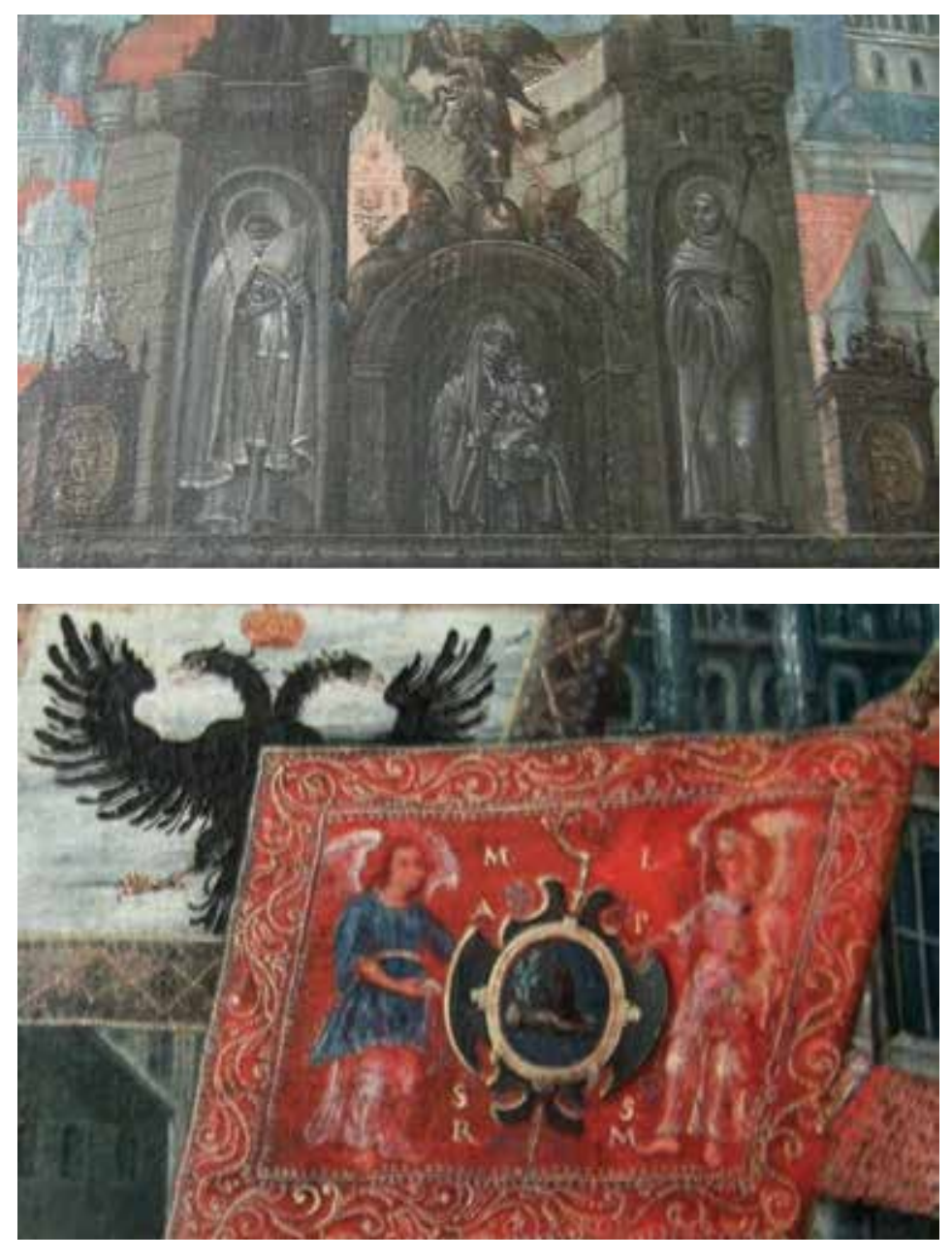

8-9. Krzysztof Boguszewski, fragmenty obrazu Wjazd św. Marcina do Amiens, $1628 \mathrm{r}$., katedra w Poznaniu. Fot. A. Stankiewicz,

analiza formalna jedynego zachowanego i potwierdzonego źródłowo dzieła malarza Wjazd św. Marcina do Amiens (il. 7). Należy zgodzić się z zasadniczymi spostrzeżeniami Ireny Głębockiej-Piotrowskiej oraz Mariusza Karpowicza. Artysta zdecydowanie preferował barwy chłodne, zielonkawe bąd́́ niebieskawe, koncentrował się na oddaniu każdego niemal jest rysempewnejniwnósistylú Świ

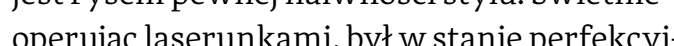
nie prze laserunkami, był w stanie perfekcyjnie przedstawiac przezroczyste i aksamitne tkaniny. Technika ta sprawdzała się również w ukazywaniu rzeczywistości niebiańskiej, prześwietlonych obłoków czy delikatnego sfumato twarzy aniołów (il. 2-3). Oblicza postaci zaludniających płótna Krzysztofa Boguszewicza z reguły mają wyraziste oczy, 
które w przypadku aniołów zdają się być nieco szkliste, jakby uchwycone w momencie uniesieni, duchowego, a w przypadku dzi - okragłe, nieco wyłupiaste. Trzeba też dodać, że przedstawiając tych ostatnich nie bał się oddawać ich brzydoty. Nie radził sobie z perspektywą linearną, ale jednocześni potrafił ukazać otaczającą go naturę i odrealnioną atmosferę zaświatów. Właśnie niezwykła „wizyjność” przedstawień niebiańskiej rzeczywistości świadczy o podjęciu próby odnalezienia własnej, odpowiedniej formuły do prezentacji stanów zachwytu i rajskiej szczę́liwości, w jakiej wszyscy irajuma

Wymienione cechy można odnaleź jedynie w niewielkiej grupie przedstawien religijnych. Bardzo ostrożni w analizach stylistycznych autorzy międzywojenni zdecydowali się na związanie z Krzysztofem Boguszewskim wszystkich obrazów z poznańskiej katedry, które po roku 1834 przeniesiono tam z kościoła cystersów w Paradyżu. Wśród nich znalazły się Niebieskie Jeruzaler i przechowywane obecnie w zbiorach Muzeum Archidiecezjalnego w Poznaniu Niepokalane Poczęcie, które wyczerpująco Niepokalane Poczęcie, które wyczerpų omówiono już pod kątem ikonografii ${ }^{4}$. W obydwóch pracach można wskazać właś wie cały repertuar środków stosowanych przez Krzysztofa Boguszewskiego; łączy je też z przedstawieniem z legendy św. Marcina fakt, że wykonane zostały na płótnie naciągniętym na deski. Najlepszymi partiam Niebieskiego Jeruzalem z całą pewnością są Niebieshiego Jeruzale przenika)ące się zoblokami postacie an tow i świętych, unoszące się ponad niezmierzonym morzem glow zbawionych, o ktorych sw. Jan Ewangelista wspominał w swojej wizji (il. 4). Trudno nie odnieść też

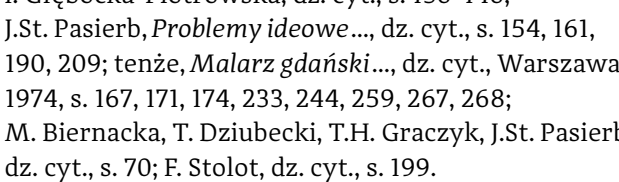

wrażenia, że Maryja w Niepokalanym Poczęciu przewyższa swoją eteryczną urodą Matkę Bożą z prac Hermana Hana, choć zewnością poziom artystyczny malowide gdańskiego malarza był wyższy.

Niewiele wiadomo o obrazie Święty awet (il. 5), wciąż eksponowanym w pocysterskim kościele w Paradyżu, wiązanym z Krzysztofem Boguszewskim przez częśc badaczy na podstawie analizy formalnej ${ }^{4}$ Wizerunek wymaga osobnych badań, w tym miejscu trzeba wspomnieć jego program ikonograficzny, nawiązujący do istotej roli misjonarskiej, jaka apostol odegrat whistorii Zbawienia Ś apty stor ode whistoril Zbawienia. Swięty

wezer przerzuconym przez ramię, prawą ręką odbiera od unoszącego się w obłokach Chrystusa - któremu towarzyszą Bóg Ojciec oraz gołębica symbolizująca Ducha Świętego - otwartą książkę z napisem „NON AB NOMINE ILLUD ACCEPI”. W lewej ręce na sznurze apostoł trzyma okrągłą mapę Europy i północnego wybrzeż A fruki, tónej krawęd zie otocyly kyrzeża Afryki kórej krązic otoczyly karty z tytułan istów świętego. Po bokach postaci unosza wę cztery symbole Ewangelistów ujęte w nimby, połączone promieniami, które biegną prosto z rąk Boga-Ojca. Świetlista gama barwna, precyzja oddanych szczególów oraz zastosowane laserunki pozwalają faktycznie zaliczyć obraz do dorobku Boguszewskiego, a złożony program ikonograficzny należałoby wiązać także i tym razem z opatem Łętowskim.

Wśród większości badaczy nie budziło wątpliwości zaliczenie do dzieł malarza wizerunku Matki Bożej na smoku z ołtarza bocznego w kościele pobernardyńskim Sierakowie ${ }^{43}$. Oczywiście, w świetle

42 A. Sławska, dz. cyt., s. 43-44; F. Stolot, dz. cyt., s. 76. 43 A. Stawska, dz. cyt., s. 43; Katalog zabytków..., dz. cyt., A. Sławska, Warszawa 1968, s. 18; A. Ryszkiewicz, M. Walicki, W. Tomkiewicz, dz. cyt., s. 334, B. Lenard,

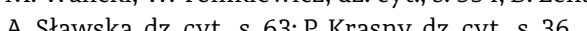

wspomnianej w testamencie wzmianki na temat pracy malarza dla Zofii z Kostków Opalińskiej faktycznie można by założyć, że któreś z płócien z tej świątyni w jego pracowni. Datowaną na rok 1629 westape zobrazem Maryiw towarzystwie św. Ludwika de Valois ísw. Bowaneystwe trudno jed de Valois isw. Bonawentury trudno jednak bezrefleksyjnie uznać za dzieło Krzysztofa Boguszewskiego. Za atrybucją przemawia hieratyczne przedstawienie postaci Matki Bożej oraz typy fizjonomiczne aniołów, ale sposób nakładania farby i kolorystyka postaci znacząco różnią sie od prac typowych dla Boguszewskiego. Nie można wykluczyć, że stan zachowania oraz późniejsze przemalowania zniweczyly ostateczny wyraz artystyczny, ale też trudno nie odnieść wrażenia, że jest to dzieło innego mistrza"s.

Pracą Krzysztofa Boguszewskiego est prawdopodobnie również maryjny wizerunek z Biechowa (il. 6). Po przeprowadzeniu konserwacii w $1962 \mathrm{r}$. okazało sie że był pierwotnie niewielkich rozmiarów przed-

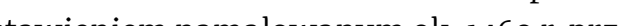
artystę ze sz Około 1632 r. płótno powiększono i przemalowano. Przypuszczalnie uczynił to sam Boguszewski, o czym świadczą wyraźn analogie z pracami paradyskimi ${ }^{46}$.

Przegląd domniemanych dzieł malarza zamyka obraz Matki Bożej w kościele

Przeciw tej propozycji zob. F. Stolot, dz. cyt., s. 75. konwentu bernord drof., t. 5, z. 13, s. 18; Kron wlatach 1624-1819, red. T. Andrzejewski, R. Jędrzejczak, A. Paczesny, tuum. M. Miazek-Męczyńska, R. Piętka, M. Szymańska-Piętka, J. Zaborowsk

$45 \mathrm{~W}$ listach Krzysztofa Opalińnkiego do jego brata dwóch pracuiących dla nich malarzy: Jurge oraz malarczyka sierakowskiego", s. Wiliński, Krzysztofa Opalińskiego stosunek do sztuki. Malarstwo i grafika, „Biuletyn Historii Sztuki”” 1955, nr 2, t. 17, s. 196. Malarz Jurga w 1616 r. pracował przy odnawiani

46 J. Wolski, dz. cyt., s. 108, 109. parafialnym w Kawnicach, który związał niegdyś z malarzem konserwator Leonard Torwirt47. Propozycja ta nie wydaje sie trafbytmale podobin do dzieł Boguszewskiego.

Dotychczasowe rozważania koncentrowały się na wskazaniu pewnych wątpliwości bądź spostrzeżeń na temat życiorysu, formacji artystycznej oraz dorobku artysty. Warto natomiast przyjrzec się uważniej relacjom malarza z jego zleceniodawcami, odpowiedzialnymi za program ikonograficzny konkretnych realizacji. Jak udowodniła Jadwiga Ruszczycówna na przykladzie Bitwy pod Grunwaldem, analiza tych zalezBitwy podGrczycowna na przykf noscipozwala dokladnis okreslic nie tylko znaczenie i kontekst dzieła, ale tez zrozumieć zakres zaangażowania artysty w proces tworzenia. Największą możliwość przeprowadzenia takich badań bez ryzyka

popełnienia błędów nadinterpretacji mamy w przypadku Wjazdu św. Marcina do Amiens, który doczekał się jak dotąd najliczniejszych, ale też - jak się okazuje - bałamutnych wzmianek w literaturze.

Naturalizm przedstawienia części postaci w tym obrazie, epickość przekazu sprawiły, że uwaga autorów skupiła się głównie na odnajdywaniu na płótnie podobizn współ czesnych malarzowi osób. Już Nikodem Pajzderski dopatrzył się w jeźdźcu w złotej zbroi króla Zygmunta III Wazy ${ }^{48}$ (il. 10). Pomysł ten podchwyciła Irena Głębocka-

-Piotrowska, która w obliczu świętego Marcina widziała młodego Jana Kazimierza, a w żbraku - cysterskiego przeora Augustyna Dobrowolskiego $0^{49}$. Z tą ostatnią interpretacją nie zgadzał się ks. Janusz St. Pasierb, któ dość ostrożnie przyjął propozycje obu

\section{R. Ukleja, Miejsca swięte w Polsce taskami i cudami słynace. Sanktuaria i miejsca kultu Matki Bożej \\ N. Paizderski, dz cyt, s. 89}

49 I. Głębocka-Piotrowska, dz. cyt., s. 131-132. 


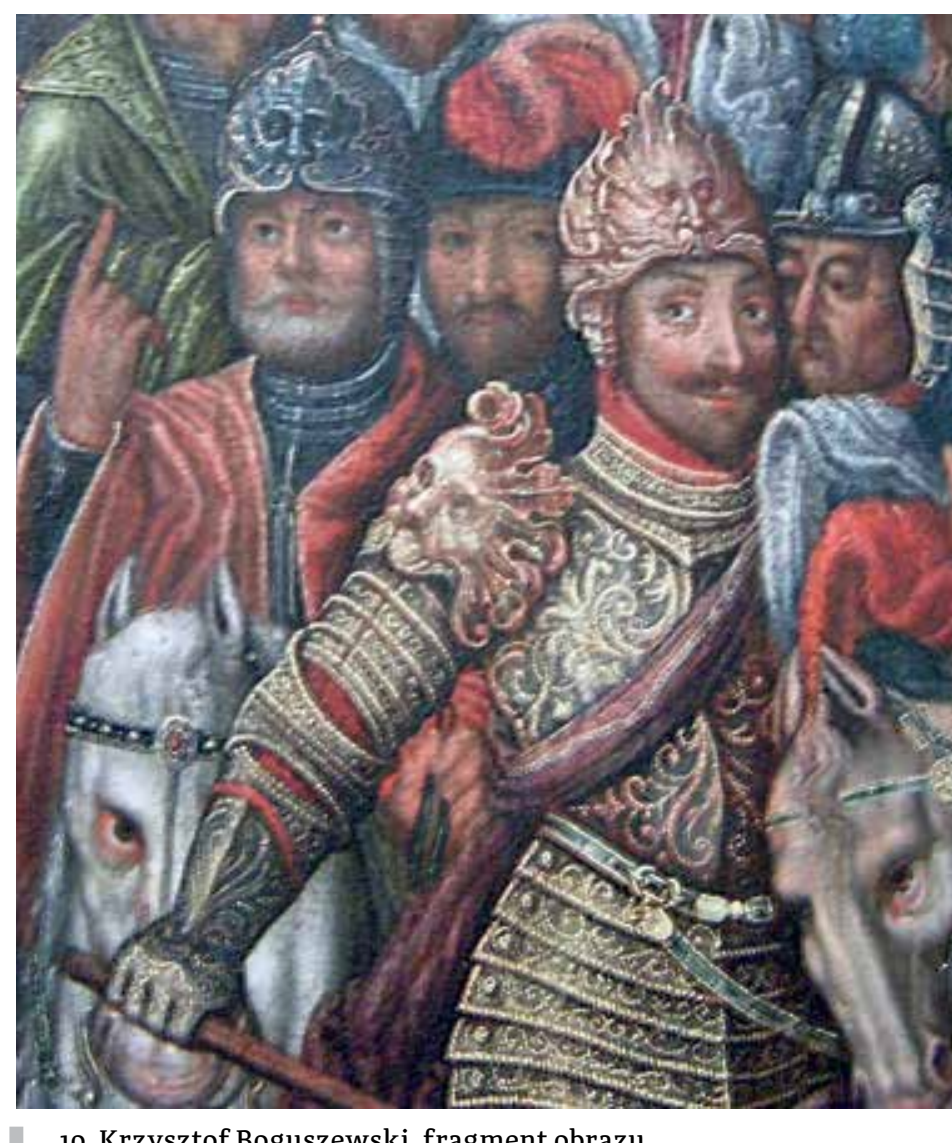

Wjazd św. Marcina do Amiens, 1628 r., katedra

Wjazd św. Marcina do Amiens, 1628
w Poznaniu. Fot. W. Hildebrandt

badaczy $y^{50}$. Poparł je i rozwinął znacząco Władysław Tomkiewicz, który pisał, że nie ma wątpliwości, że są to podobizny Zygmunta III i jego najbliższego otoczenia ${ }^{5}$. Powołując się na portrety z epoki, dopatrzy się w obrazie wizerunku Lwa Sapiehy i Mikołaja Wolskiego, a w świętym - królewicza Władysława, mimo że nie potrafił poprzeć tej propozycji żadnym argumentem ${ }^{52}$ Taką interpretację powtórzyli wszyscy późniejsi autorzy ${ }^{53}$. W dziele Krzysztof Boguszewskiego doszukiwano się rozbieżBoguszewskiego doszukiwano się rozbież-
nych cech stylowych, charakterystycznych dla malarza, podkreślając fakt udziału

50 J.St. Pasierb, Malarz gdański..., dz. cyt., s. 233. 51 W. Tomkiewicz, Aktualizm..., dz. cyt..s. 79. 52 Tamże, s. 79-80.

53 E. Kręglewska-Foksowicz, E. Linette, J. Powidzki, W. Tomkkiewicz, dz. cyt., s. 334; F. Stoloto, dz. cyt., s. 76 . Krzyszztofowicz-Kozakowska, F. Stolot, dz. cyt. 199. I. Zuk kowski, dz cyt s. 185 . w powstaniu programu ideowego dzieła opata Łętowskiego, co miałby potwierdzać podpis umieszczony u dołu płótna. Zwracano też miejskiego pejzażu Amiens ${ }^{54}$

Według treści inskrypcji zamieszczonej w dolnej partii obrazu, został on namalowany przez Krzysztofa Aleksandra Boguszewskiego według inwencji opata paradyskiego, Marka Łętowskiego w $1628 \mathrm{r}$. Jego powstanie łączono dotychczas z zamówieniem wspomnianych wyżej innych prac Boguszewskiego do kościoła cystersów w Paradyżu i najwyraźniej miało związek $\mathrm{z}$ akcją wymiany wyposażenia w tej świątyni w myśl zaleceń zawartych w statutach generalnych zakonu z 1601 r..55 Inicjatorem tych zmian był wspomniany już Marek Łętowski, królewski sekretarz i wychowawca królewicza Władysława, opat w Paradyżu w latach 1617-1629, odpowiedzialny nie tylko za gospodarczy rozwój klasztoru $^{56}$, ale także za fundację licznych zachowanych do dziś precjozów ${ }^{5}$. Inicjatywy duchownego miały dla niego duże znacenie, skorowszystkie zostary opatrzone jego herbem ${ }^{58}$ i inicjałami (il. 9)

54 T. Chrzanowski, dz. cyt., s. 96-98.

55 J. Nowiński, Ars cisterciensis. Kościół cysterski w średniowieczu- wyposażenie i wystrój, Warszawa 2016, s. 352-353.

56 G. Dogiel, Paradyż. Opactwo pocysterskie i jego zabytkowy zespót (historia - rewaloryzacja), Kraków

57 R. Gapski, Złotnicze fundacje opata tetotowskiego dla z. 4, s. 215-225. W literaturze można spotká się $\mathrm{z}$ opiniami, że w wyniku wielkiego pożaru opactwa paradyskiego w 1633 r. spłonęło wnętrze kościoła. Zachowane obrazy i złotnictwo zdają się podważac taka interpretacje wzmianek o tej katastrofie.
S. Wilinślki Gotychi kościót pocystershiego paradyskiego w Gościkowie. Poznnán 1953 op. 14 B. Grabowska, Paradyż i Raj Utracony, Gorzów Wielkopolski 2010, s. 23 .

58 Nazwę herbu Niezgoda przyjęto za późniejsza
tradycia. K. Niesiecki, Herbarz polski, t. 5, Lipsk 18 s. 248. Eętowscy wywodzili się z gałęzi pomorskiego które są także widoczne na obrazie Krzysztofa Boguszewskiego na jedne z chorągwi ponad jeźdźcami.

Przedstawiona scena została wyraźnie oparta na tekście Legenda Aurea Jakuba de Voragine'a ${ }^{59}$. Wjazd legionisty rzymskiego Marcina do Amiens, w trakcie którego użyczył on części swojego płaszcza żebrakow Krzysztof Boguszewski ukazał w zimie, o czym świadczy przerębel oraz zasypany śniegiem stóg siana. Na drugim planie, za świętym, artysta namalował wjeżdżający do miasta orszak jeźdźców, wśród których wyróżnia się grupa rozmawiających zbrojwy nych. Fikcy na architeltura Amiens skład się z budowlio proweniencji sredniowiecznej i wczesnonowożytnej, niderlandyzującej. Warto zwrócić uwagę, że Boguszewsk pragnąc przekonać widzów, że jest to miasto francuskie, na bramie wjazdowej umiescił nie tylko heraldyczne lilie na tarczach, ale też wśród płaskorzeźb, flankujących wizerunek Matki Bożej, wyobraził św. Dionizego, patrona Francji, oraz św. Bernarda z Clairvaux (il. 8). Ponad miastem, łamiąc zasadę jedności miejsca i czasu, unoszą się chóry niebiańskie otaczające

Chrystusa, który w ręce trzyma darowany mu przez świętego fragment szaty. Staranność ukazania przebiegu historii dowodzi chęci prezentacji historycznych okoliczności wydarzenia, a nie aktualizacji sceny. Antykizacja zbroi jeźdźców oraz św. Marcina, ukazanego w stroju rzymskiego legionisty miała nawiązywać do rzeczywiceczyw ter podkresajaz zdobione maskam hełmy oraz naramienniki w formie lwich pysków, w nowożytnym płatnerstwie stosowanych jako odwołanie do konwencji all'antica ${ }^{60}$. lub von Lantow. P. Pragert, Herbarz szlachty
kaszubskiej, t. 2, Gdansk-Wejherowo 2007, s. 122-123. 59 J. de Voragine, Złota Legenda. Wybór, tuum. J. Pleziwa, oprac. M. Plezia, Warszawa 1954, s. 639 60 S.W. Pyhrr, J.A. Godoy, S. Leydi, Heroic Armor of the
Ponadto na jednej z chorągwi wyobrażono dwugłowego Orła Swiętego Cesarstwa Rzymskiego Narodu Niemieckiego (il. które w powszechnej świadomości ówczeany snych Europejczyków uchodziło za ideow kontynuację cesarstwa rzymskiego $0^{61}$. Za ewentualną aktualizację można uznać heł my w typie przyłbicy, regiment $w$ ręce jednego ze zbrojnych oraz szyszaki używane w początku XVII w. przez szwedzkich kirasjerów i polskich husarzy.

Osobnych badań wciąż wymaga sprawa kryptoportretów (il. 10). O ile faktycznie twarze cześci jeźdźców zdro portretowy charakter, to jednak niektóre dotychezasowe iter, to jecje neprzekonuju. Moża zodzić sie z propezycju ze wo tej zbroi zodzlc siez z propozycja, ze wzloWaze, a Wazę, a wśród osób mu towarzyszących można dostrzec też Lwa Sapiehę, ale św. Marcin nie jest podobny ani do królewicza Władysława, ani do Jana Kazimierza ${ }^{62}$. Wątpliwości budzi też postać żebraka (il. 11). Racje miał ks. Janusz St Pasierb, który wola w nim widziéc Marka Letowskiego, a ne Augustyna Dobrowolskiego's, ko, a obją urząd przeora w roku 1642, a w roku 1628 by zaledwie młodym nowicjuszem ${ }^{64}$. Dobór sportretowanych osób wynikał ze znajomo ści dworskich dostojników przez

Łętowskiego, jak wspomniano wcześniej, wychowawcę królewicza Władysława cę programu ikonograficznego.

$$
\text { Sytuacja, w której zleceniodawca sa- }
$$

modzielnie wymý́lał temat i czuwal nad

\section{ries [katalog wystawy], The Metropolitan Museum}

61 C.S. Wood, Maximilian I as Archeologist, ,Renaissance , t. 58, s. 1138.

62 W. Tomkiewicz, Aktualizm..., dz. cyt., s. 79-80.

63 J.St. Pasierb, Malarz gdanski..., dz. cyt., s. 233.

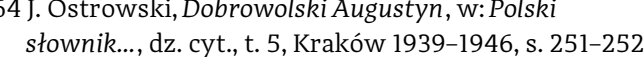
Automatycznie należy odrzucić propozycję, by portret trumienny Augustyna Dobrowolskiego (zm. 1665) przypisywwać Krzysztofowi Boguszewski- 


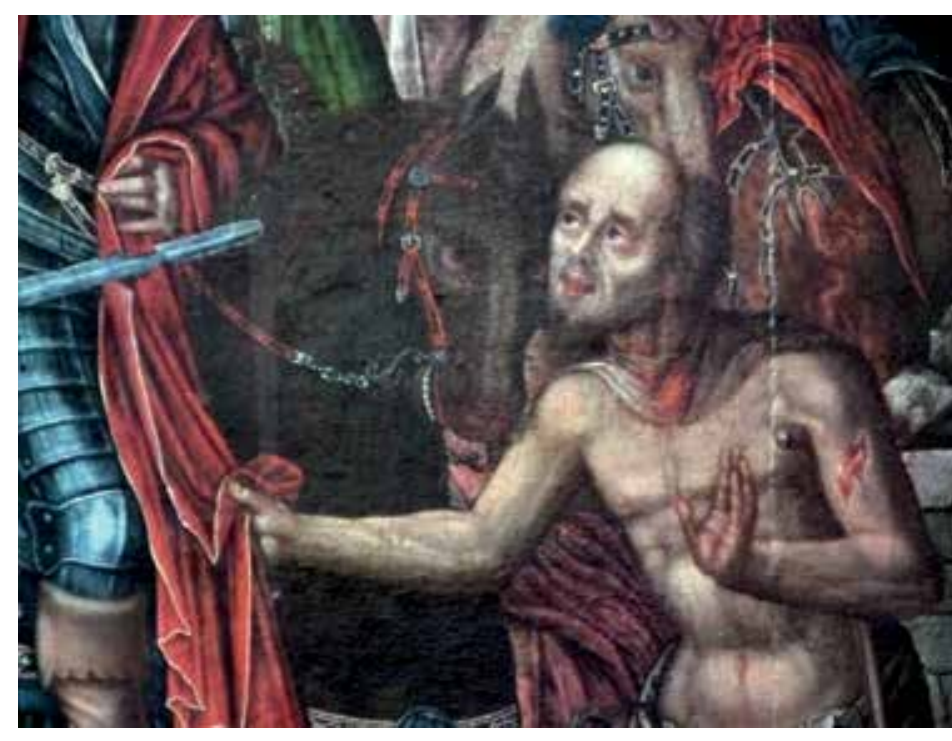

11. Krzysztof Boguszewski, fragment obrazu Wjazd św. Marcina do Amiens, 1628 r., katedra w Poznaniu. Fot. W. Hildebrandt

jego realizacją, sygnując dzieło jako jego współtwórca, była dość niezwykła w praktyce malarskiej XVII w, i epok wcześniejszych Z reguły ma alarz otrzymywał jedyni ogólne ramy tematyczne od fundatora,

a sam - posiłkując się rycinami, książkami lub własnym doświadczeniem - komponował szczegóły. Znaczna ingerencja duchownego w prace nad obrazem mogła być wynkiem zaleceń sformułowanych przez niektórych uczestników soboru trydenckiego. W 1601 r. biskup krakowski Bernard Maciejowski w Epistola pastoralis zalecał taką postawe odwolując się do pism arcybit taka posta ten został nastepnie uznany za instrukcję dla całej gnieźnieńskiej archidiecezji

całej gnieźnieńskiej archidiecezji w Piotrkowie Trybunalskim w 1628 r. Druku
w Poznaniu doczekał się dopiero w 1640 r..$^{65}$ Stosunkowo wczesną recepcję ustaleń soborowych przez Marka Łętowskiego należałoby rozpatrywać w kontekście działań zmierzających do odnowy Kościoła, w których malarstwo miało pełnić rolę wistotnego medium. Kopiowa istotnego medium. Kopiowanie przez Krzysztofa Boguszewskiego kompozycji prac Hermana Hana nie było tylko zapożyczeniem formalnym, ale świadomym

65 P. Krasny,E Epistola pastoralis biskupa Maciejewskiego z roku 1601.Zapomniany dokument recepcij potryden kich zasad kształtowania sztuki sakralnej w Polsce, powtórzeniem sprawdzonych już w innych klasztorach wzorów. Bardzo prawdopodobne, że Łętowski chciał nassadować programy ideowe z wnętrzinnych cysterskich kościołów, m.in. Pelplina, i dokonał wymiany wyposażenia kościelnego. Zresztą, atmos fera odnowy przeniknęła w tym czasie i inne zakony. Dominikanin Fabian Birkowski pisał: „co pismo czytającym, to prostaczkom patrzącym daje malowanie; patrząc na nie, widzą czego mają naśladować, na tym czytają, którzy czytać nie umieją. [...] ta reprezentacyja żywa więcej go drugdy uczy i wzrusza aniż słowa kazo dragdy uczy" i wzresza aniz stowa kaznodziejoco ne dwojako - z jednej strony obraz był odczytywany jako sposób na prezentację prawd wiary, z drugiej - jako rodzaj bardzie złożonego programu teologicznego, nieraz na sposób klasycznie rozumianych emblematów. I w takim kontekście Wjazd św. Marcina może być traktowany jako zachęta do praktykowania cnoty miłosierdzia ${ }^{67}$.

$$
\text { Niewykluczone, że również w przy- }
$$$$
\text { padku samego Krzysztofa Boguszewskiego }
$$

mamy doczynienizz malarzennadizą-

cym za postulatami reformatorskimi,

a przynajmniej dobrze zorientowanym

w nowych wymaganiach. Warto w tym

miejscu wspomnieć, że jako autor wizerunku Matki Bożej z Otorowa, byłby jednym z pierwszych wielkopolskich malarzy, który zastosował zalecony w $1621 \mathrm{r}$. przez synod krakowski typ rzymskiej Salus Populi Romani ${ }^{68}$. Ale są też inne przesłanki. Autorzy odnowy potrydenckiej zakładali również bezpośredni udział w reformie samych artystów. U podstaw działalności rzymskiego

66 W. Tomkiewicz, O sztuce barokowej w Polsce, w: tenże, Pędzlem..., dz. cyt., s. 12

67 Epizod z Amiens zlegendy o św. Marcinie odczytywano w ten sposób od średniowiecza. M. Walczak, Miracles et Charité dans liconographie Martinienn w:Martin de Tours: Le Rayonnement de la cité, 68 P. Krasny Epistola. dz cyt,s. 137. oratorium Filipa Nereusza legła dysputa teologiczna i tłumaczenie prawd wiary w gronie specjalnie zapraszanych twórców, głównie malarzy. Z kolei według cześc nie malán, $z$ koj. Paleottiego czy Fyderyka Borome dy artysta poprzez swọ Bor Kościo popzez swoją twórczość od Kościołowi mógł osiągnąć zbawienie ${ }^{6 .}$. W kontekście działalności Boguszewskiego trudno nie odnieść wrażenia, że malarz ten poza wnikliwą analizą tekstów religijnych, na podstawie których z całym spokojem mógł samodzielnie przygotować program ikonograficzny Niepohalanego Poczęcia czy Niebiesigo Jeruzalm, usilowal takz czy Niebieshiego Jenzakn, usilowa takie sp nić i ten postulat. Przyjęcie przez niego swięceń można oczywišcie interpretować jako próbę zdobycia stałego zarobku, ale juž fundacja Bractwa Aniołów Stróżów świadczy o znaczącym zaangażowaniu w dzieło odnowy Kościoła.

Powyższe rozważania są zaledwie zarysem problematyki związanej z działalnością Boguszewskiego i wstępem do o wiele powazniejszego zagadnienia ja wie Bow jakim są badania nadcalym zarswechowym dawnego województwa poznanskiego. Z pewnością tworczośc Boguszewskiego zajmuje w nim poczesne i wcale nie marginalne miejsce.

\section{SOME REMARKS ON ARTISTIC WORK OF KRZYSZTOF}

\section{BOGUSZEWSKI}

\section{ALEKSANDER STANKIEWICZ}

The article deals with the artistic activity o Krzysztof Aleksander Boguszewski (d. 1635), nobleman, spiritual and painter, active in Poznań in years 1624-1635. In the past,

69 Tenże, Visibilia signa ad pietatem excitantes. Teoria sztuki sakralnej w pismach pisarzy kościelnych epo scholars tried to do all they could to expand his oeuvre by resorting to imprecise comparisons or overinterpretation of his works. Also, they wanted to found style of his paintings in works of Herman Han. In the light of documents, it is sure that Boguszewski wa not the imitator or even pupil of Han. $\mathrm{He}$ probably learned to paint in confraternity of painters in Lublin or Lwów.

In fact, we can only proof his signature in one existing work - The entry of St. Martin into Amiens from 1628, originally from Cistercian church in Paradyż, but today exposed in Poznań cathedral. Other paintings from Paradyż Abbey, like The Heavenly Jerusalem (1628?), The Immaculate Conception (1628?) and St. Paul (1628?) and effigies of St. Mary from church in Otorów and Biechów (1632) we can include in the works of Boguszewski using the compare method. The other painting attributed by scholars to artist are fundamentally different.

The iconography of his works from Paradyż were projected by the Cistercian abbot, Marek tętowski (d. 1629) His concetion for Boguszewski works was based on the instructions of Church intellectualist, like Carlo Borromeo or Gabriele Paleotti. It is very probably, that the painter, who became a priest in parish church of St. Adalbert in Poznań in 1630, was personally involved in the idea of artists working for the reform of the Church after the council of Trent.

\section{SLOWA KLUCZOWE / KEYWORDS:}

Krzysztof Boguszewski, ikonografia

malarstwo manierystyczne,

kontrreformacja

Krzysztof Boguszewski, iconography,

mannerism painting, Counter-

-reformation 